\title{
First report of southern blight caused by Sclerotium rolfsii on sesame in Mexico
}

\author{
Javier Hernández-Morales ${ }^{1}$. Daniel Leobardo Ochoa-Martínez ${ }^{1}$. Victoria Ayala-Escobar ${ }^{1}$. \\ Santo Ángel Ortega-Acosta ${ }^{1}$
}

Published online: 27 March 2018

(C) Società Italiana di Patologia Vegetale (S.I.Pa.V.) 2018

Sesame (Sesamum indicum L.) is an oleaginous crop of great importance worldwide. During December 2015, in sesame plantations of Guerrero, Mexico, plants with root and basal stem rot were collected. Compact mycelial masses and numerous whitish to dark brown sclerotia were observed on these plants. Pieces of tissue were cut from the lesion and disinfested with $1.5 \% \mathrm{NaOCl}$, transferred to PDA and incubated at $28{ }^{\circ} \mathrm{C}$. After one week, pure cultures were obtained. Subsequently, after 21 days of incubation, colonies developed white, silky mycelium and abundant globoid to irregular sclerotia, 1 to $3 \mathrm{~mm}$ in diameter. Based on morphological characteristics, the fungus was identified as Athelia (Sclerotium) rolfsii (Mordue 1974). Identification was confirmed by amplifying and sequencing a $658 \mathrm{bp}$ fragment of the ITS region using ITS1/ITS4 primers (GenBank accession No. MF428429) (White et al. 1990). This sequence showed 99\%

Santo Ángel Ortega-Acosta

ortega.santo@colpos.mx

1 Colegio de Postgraduados, Postgrado en Fitosanidad-Fitopatología, Km. 36.5 Carretera México-Texcoco, Texcoco, Mexico identity with Athelia rolfsii (teleomorph of $S$. rolfsii) (AB042626 and AB075298). Pathogenicity tests were carried out on 20 healthy sesame plants in a greenhouse at $24 \pm 2{ }^{\circ} \mathrm{C}$. A mycelial plug of $S$. rolfsii was deposited at the base of each plant. In ten plants a sterile PDA plug was placed to serve as uninoculated controls. After 25 days, inoculated plants exhibited symptoms similar to those observed in the field, from which $S$. rolfsii was re-isolated and identified morphologically. In control plants, no damage was observed. S. rolfsii has been reported to infect sesame in Korea, Taiwan, Cambodia, Cuba, Greece, and India (Farr and Rossman 2017). This is the first report of $S$. rolfsii causing southern blight on sesame in Mexico.

\section{References}

Farr DF, Rossman AY (2017) Fungal databases, systematic mycology and microbiology laboratory, ARS, USDA. Available from: http://nt.ers-grin.gov/fungaldatabases

Mordue JE (1974) CMI Descriptions of Pathogenic Fungi and Bacteria. No. 410. CAB International, Wallingford

White T, Bruns T, Lee S, Taylor J (1990) Amplification and direct sequencing of fungal ribosomal RNA genes for phylogenetics. In: Innis MA, Gelfand DH, Sninsky JJ, White TJ (eds) PCR protocols: a guide to methods and applications. Academic Press, San Diego 